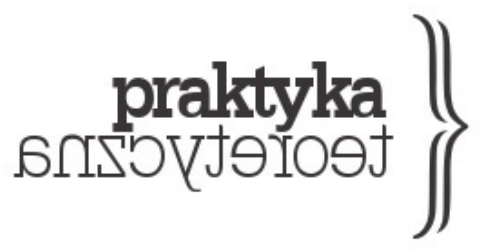

ISSN 2081-8130

DOI: $10.14746 / p r t .2019 .1 .5$ www.praktykateoretyczna.pl

\title{
Communism as a General Crime: Applying Hegemony ANALYSIS TO ANTI-COMMUNIST DISCOURSE IN CONTEMPORARY POLAND
}

\author{
MICHALINA GOLINCZAK
}

\begin{abstract}
With the collapse of state socialism in Eastern Europe, anti-communism has gained new momentum. In Poland, it has become a hegemonic discourse that manifests itself in (and reproduces itself through) legislation, public history, politics, and education, as well as pop culture. However, the discursive dominance of anti-communism has hardly been researched systematically. In this article, I aim to apply hegemony analysis - as developed by Martin Nonhoff and based on Ernesto Laclau and Chantal Mouffe's theory of discourse - to anticommunism in contemporary Poland. I give an overview of the methodology, discuss concrete analytical tools and their possible application and argue that, as a result of an antagonistic division of discursive space, communism becomes a "general crime", an obstacle that prevents Polish society from finding "ultimate reconciliation with itself" and reaching its (mythical) fullness.
\end{abstract}

Keywords: anti-communism, discourse, hegemony (analysis), Laclau, Mouffe, Nonhoff 
With the collapse of state socialism in Eastern Europe, as well as the narrative of the "end of history" and the superiority of capitalism and liberal democracy, anti-communism has gained new momentum (Žižek 2009; Kapmann, Müller, and Stojaković 2017, 11). Enzo Traverso even speaks of "a new wave of anti-communism: a 'militant', fighting anti-communism, all the more paradoxical inasmuch as its enemy had ceased to exist" (2016). In Poland, as in some other post-socialist states (cf. Holubec and Mrozik 2018), ${ }^{1}$ it has become one of the key political discourses (Żukowski 2009; Saryusz-Wolska, Stach, and Stoll 2016; Janicka 2016) and may even be perceived as a discursive foundation of the Third Republic (Walicki 2013, 199-201). ${ }^{2}$ All socially relevant forces, including most of the left, share the anti-communist consensus (Mrozik 2014). Polish anti-communism takes different, sometimes contradictory, forms: from opposition to Marxism and classical theorists of communism, to an over-simplified critique of the People's Republic of Poland, ${ }^{3}$ to a general rejection of leftist or even liberal ideas (cf. Mrozik 2015). It manifests itself in legislation, public history, education, and everyday political life, as well as in pop culture. Although its scale is so remarkable, its hegemony so uncontested, and its manifestations so diverse, the current discursive dominance of anti-communism has not yet been researched systematically. ${ }^{4}$

One of the reasons might be that anti-communism is a relatively young research area. As historian Bernd Faulenbach claims, its significant historisation began only after the downfall of the socialist European states around 1989 (Faulenbach 2017). There are studies that focus primarily on specific historical periods in different countries. For example, in Germany, the role of anti-communism in Nazi ideology and during the Adenauer era has been relatively well explored (Körner 2003; Korte 2009; Creuzberger and Hoffmann 2014). The same can be said of the so-called "Red Scare" and the McCarthy era in the US (Murray 1964; Fried 1997; Heale 1990, 1998; Ceplair 2011; Storrs 2013). But the existing research is limited in time, mainly

\footnotetext{
${ }^{1}$ Holubec and Mrozik claim that " $[\mathrm{t}]$ he principal cause of this rise of anti-communism appears to be the failure of the dominant transformations narratives - such as the 'catch up with the West' and the 'building of democracy' - and the disappointment of Eastern European societies, especially Polish, Hungarian or Romanian, with their elites perceived as reincarnations of communism” (Holubec and Mrozik 2018, 14).

2 According to Walicki, the Third Republic of Poland was born as "an ideological project of radical rightwing anti-communism" (Walicki 2013, 200). He points out that Lech Wałęsa did not receive the presidential insignia on December 22, 1990, from outgoing president Wojciech Jaruzelski, who had not been invited to the ceremony, but from Ryszard Kaczorowski, the president of the London-based government-in-exile. The term "Third Republic" (Trzecia Rzeczpospolita), describing Poland after the political-economic changes of 19891990 , is not an official one, but it appears in the preamble of the 1997 constitution.

${ }^{3}$ That is, a critique that is not aimed at criticising some aspects of the People's Republic of Poland but in fact is a condemnation of communism (socialism) en bloc.

4 This does not mean that some particular aspects have not been studied. For example, the antisemitic topos of "Jewish Communism" ("żydokomuna") has been researched quite thoroughly, see: Gerrits 1995; Blatman 1997; Pufelska 2007; Zawadzka 2009, 2012, 2016; Starnawski 2012; Śpiewak 2012; Forecki 2017.
} 
focusing on the period between the beginning of the $20^{\text {th }}$ century and the end of the Cold War. Therefore, present-day anti-communism, not only in Poland, has not been adequately studied. ${ }^{5}$

One of the difficulties in research on this topic involves terminological matters and the fact that the term "anti-communism" has been intensely politically disputed; even regarding its definition "opinions in the political-scientific discussions (...) differ considerably", as Faulenbach notes (Faulenbach 2011, 1). In this paper, I use a broad definition of anticommunism that allows me to take into account the multitude of its manifestations in contemporary Poland. In practice, this means that my work is not based on a certain definition of "communism" but rather explores how the term is used in political discourses (cf. OSKiLnK 2013).

This article proposes to apply hegemony analysis to anti-communist discourse in Poland. After giving an overview of the methodology as developed by Martin Nonhoff, I proceed to discuss concrete theoretical tools and their possible application, using various examples from the period after 1989. These are not selected systematically but rather aim to show the broad scope of anti-communism. It should be emphasised that this paper has an introductory purpose and does not claim to give a full overview of either Nonhoff's approach or Laclau and Mouffe's discourse and hegemony theory. It introduces only those aspects and concepts that are relevant for the analysis of the hegemony of anti-communism and aims at starting a debate, rather than giving definitive answers. Therefore, some aspects that are fundamental to hegemony theory, such as the relationship between discourse and subject, are not discussed in this article.

\section{Hegemony analysis as political discourse analysis}

The hegemony analysis applied in this article is a method used for the analysis of political discourses, developed by political scientist and professor of political theory at the University of Bremen Martin Nonhoff (2006). His approach is based on Ernesto Laclau and Chantal Mouffe's theory of discourse as introduced in their collective work Hegemony and Socialist Strategy. Towards a Radical Democratic Politics (2014 [1985]) as well as its further development by Laclau (Nonhoff 2006, 18). Nonhoff aims to close a "methodology gap" by making their theory more

\footnotetext{
5 In the Polish context, anti-communism among right-wing parties and political groups during the period 1989-2000 has been analysed in detail by Artur Lipiński (2005). I would also like to point out the work of the Centre for Cultural and Literary Studies of Communism at the Institute of Literary Research at the Polish Academy of Sciences, founded 2011, and its book series "Communism. Ideas - Discourses - Practices" ("Komunizm. Idee - Dyskursy - Praktyki"), which - going against the dominant narratives about communism - is unique in the Polish academic landscape. One can also observe a rising interest in anti-communism in journalistic texts: see, for example, two issues of the quarterly Bez Dogmatu (79/2009 and 116/2018) with a series of articles on anti-communism in Poland after 1989; Wielgosz 2017; Herer 2017.
} 
suitable for empirical analysis (Nonhoff 2008, 300; 2019, 64). ${ }^{6} \mathrm{He}$ uses it to analyse the discourse of the "social market economy" in Germany during the 1940s and 1950s. However, in doing so, he is less concerned with the specifics of how and why the hegemony of the "social market economy" has been established but instead focuses on the more general question of "how hegemony is being exercised, in which structures and mechanisms it is grounded, and which factors are characteristic of its success" (Nonhoff 2006, 10).

Nonhoff's hegemony analysis focuses on political discourses, understood as discourses in which a (specific) universal is being disputed in a conflictual manner (Nonhoff 2006, 19). Its approach - following Laclau and Mouffe - does not distinguish between discursive and nondiscursive practices and perceives discourse as prior to the distinction between linguistic and extra-linguistic, since it includes both linguistic and non-linguistic elements. As Laclau and Mouffe emphasise: "[B]y discourse we do not mean a combination of speech and writing, but rather that speech and writing are themselves but internal components of discursive totalities" (Laclau and Mouffe 1987, 82). They define discourse as "the structured totality resulting from the articulatory practice" (Laclau and Mouffe 2014, 91), i.e. from the practice of differentiation between elements and, as a result, the production of meaning and its partial and temporary fixation through privileged discursive points. Following Saussurean linguistics (Saussure 1959), a term like "communism" gains its meaning only in the process of differentiating it from, and in relation to, other terms, such as "capitalism", "social democracy", and so on (cf. Torfing 1999, 87). Meaning is not fixed permanently and - to anticipate the subsequent reflections on hegemony - " $[\mathrm{t}] \mathrm{o}$ contend that there exists such a given meaning must be considered a hegemonic move in itself" (Nonhoff 2005, 13).

Hegemony is the second key notion that Nonhoff adopts from Laclau and Mouffe. The authors of Hegemony and Socialist Strategy, in turn, refer to Antonio Gramsci, who distinguishes between domination on the one hand and "intellectual and moral leadership" on the other (Gramsci 1999, 212). To him, rather than open coercion, hegemony is based on a kind of political agreement and consensus. However, this does not mean that it is purely consensual (cf. Opratko 2012, 63), since Gramsci perceives it as a "combination of force and consent, which balance each other reciprocally, without force predominating excessively over consent" (Gramsci 1999, 248).

Laclau and Mouffe understand hegemony as a process or a relation "by which a certain particular content overflows its own particularity and becomes the incarnation of the absent

\footnotetext{
${ }^{6}$ There are several analyses inspired by Laclau and Mouffe's theory and the so-called Essex School, e.g. of populism and nationalism, environmental movements, political identities, European integration and security policy. See: Howarth, Norval, and Stavrakakis 2000; Howarth and Torfing 2005.
} 
fullness of society" (Laclau 1995, 89) or "the name of an utterly incommensurable universality" (Laclau 2006, 648). The former illustrates this point as follows:

Let us suppose a situation of generalized social disorder: in such a situation "order" becomes the name of an absent fullness, and if that fullness is constitutively unachievable it cannot have any content of its own, any form of self-representation. "Order" becomes thus autonomous vis-à-vis any particular order as far as it is the name of an absent fullness that no concrete social order can achieve (...). That fullness is present, however, as that which is absent and needs as a result to be represented in some way. Now, its means of representation will be constitutively inadequate, for they can only be particular contents which assume, in certain circumstances, a function or representation of the impossible universality of the community (Laclau 1995, 89).

In their definition of hegemony, Laclau and Mouffe draw on (Lacan's) psychoanalysis and the experience of lack. ${ }^{7}$ They explain what, from the psychoanalytical point of view, is "the moment of the mythical fullness for which we search in vain: the restoration of the mother/child unity (...) [is], in political terms, the fully reconciled society” (Laclau 2005a, 119). This (purely mythical) social fullness is to be achieved only through hegemony (ibid.):

[V]arious political forces can compete in their efforts to present their particular objectives as those which carry out the filling of that lack. To hegemonize something is exactly to carry out this filling function (Laclau 1996, 44).

In a similar sense, Simon Critchley speaks of "hegemonization" as "actions that attempt to fix the meaning of social relations" (Critchley 2004, 113). Following Gramsci, Laclau, and Mouffe, Nonhoff defines hegemony not as the predominance of particular individuals or groups but as "the predominance of a certain constellation of socially shared meaning" (Nonhoff 2006, 11). In other words, hegemony is about generating social naturalness, universal validity, or normality (Nonhoff 2006, 40).

\footnotetext{
${ }^{7}$ Lacan's psychoanalysis plays an important role in hegemony and discourse theory, but further elaboration on it would exceed the scope of this paper. Laclau's empty signifier would, for example, correspond to Lacan's master signifier, the impossibility of society - to the impossibility of the sexual relation, and so on (Glynos and Stavrakakis 2004). The hegemonic logic is, as Laclau claims, identical to the logic of the objet petit a (Laclau 2005a, 115-116).
} 


\section{Hegemonic demands and discursive relations}

Nonhoff starts his analysis of hegemony by looking at the smallest part of discourse, which, following Laclau, he calls "demand" (Laclau 2005a, 73). He identifies three types of hegemonic demands (Nonhoff 2006, 119), all of which can be retraced in anti-communist discourse. Firstly, there are cumulative demands, which substantiate a particular aspect of the universal and can always be complemented by additional cumulative demands (ibid.). For example, changing street names in order to "overcome" the communist past is a very specific demand, which can easily be supplemented by additional demands, such as banning communist symbols or tearing down monuments. Secondly, there are subsuming demands, which claim that if they are met, then so too will other hegemonic demands (ibid.). For example, a demand to defend the "Polish nation" against the "onslaught of cultural Marxism" also implies that a successful defence would save Christianity and "traditional family values" from the disintegrating influences of "gender ideology", etc. In this case, a nationalist anti-communist demand goes hand in hand with religious and patriarchal ones. Thirdly, there are encompassing demands, the fulfilment of which constitutes a sufficient condition for the rectification of the lack of the universal (ibid.). An example would be the famous sentence of Poland's first post-communist prime minister Tadeusz Mazowiecki (1989): "We draw a thick line under the past", implying that communism is over once and for all, and society can finally return to normality.

According to Nonhoff, the struggle for hegemony can be divided into three different but overlapping steps (Nonhoff 2006, 140-141). The first step contains hegemonic articulations, attempting to expand their influence in the field of competing discourses. In the second step, these articulations constitute a hegemonic project, which can be described as political discourse with a pivotal promise striving towards hegemony. Finally, in the third step, we can speak of an established hegemony; if "a demand [is] in fact across a longer period of time [it will] be disseminated as the common will of the politico-societal forces" (Nonhoff 2005). However, it should be mentioned that the establishment of this "common will" does not mean that there are no deviating opinions. Hegemony is about predominance, not total domination, and can therefore never be total. Its reach in terms of content, space, and time is always limited (Nonhoff 2006, 147).

Hegemony analysis focuses on relations between discursive elements; Nonhoff distinguishes five types of these (Nonhoff 2006, 86-88). Difference (" $x$ is different from $y$ ") is the basic relation between all discursive elements and can be retraced in all other discursive relations. In a relation of equivalence (" $x$ is different from $y$, but in relation to $a$ both go hand in hand"), two elements are articulated as different from each other but equivalent with regard to a third one. An example of this relation would be a typical argument stemming from the theory 
of totalitarianism, as present in Polish legislation after 1989. ${ }^{8}$ It runs as follows: Communism may differ from fascism, but both are totalitarian systems that are responsible for the death of millions of people. Moving on, the relation of contrariness (" $x$ is different from $y$, and in relation to $a$ it is blocked by $y$ ") explicitly articulates the impossibility of a connection between two elements and sets them in opposition to each other (but not in every regard). The common claim in neoliberal discourse comes to mind, which contrasts the alleged mentality of a "homo sovieticus" with an "entrepreneurial spirit" and states that the former is incompatible with the free market (cf. Żukowski 2012; Buchowski 2013). Even stronger is the relation of super-difference (" $x$ is different from $y$, and it has nothing at all to do with $y$ "), which separates "discursive arenas" and emphasises the difference between two discursive elements by articulating that they are not only different from each other, but that there is no connection between them whatsoever, not even in a negative sense. A characteristic example of this relation is found in the infamous quote by ex-Foreign Minister Witold Waszczykowski:

\begin{abstract}
The previous government implemented a left-wing concept as if the world had to move using a Marxist model in only one direction: towards a mixture of cultures and races, a world of cyclists and vegetarians, who only use renewable energy sources and combat all forms of religion. This has nothing in common with traditional Polish values (Waszczykowski 2016).
\end{abstract}

Finally, in a relation of representation (" $x$ stands for $y$ "), one element embodies a second one:

When we hear Gazeta Wyborcza, we think of Trybuna Ludu. When we hear PO, we think of PZPR. And when we see a high-ranking representative of the government, the first thing that comes to our mind is "Down with Communism!" (Winnicki 2012).9

Nonhoffs five discursive relations might be expanded by a sixth: identification (" $x$ is identical to $y$ with regard to $a$ "). This relation is similar to equivalence but with a different emphasis. While in the relation of equivalence, two elements are different in general but equivalent with regard to a third one, in the relation of identification, two elements are perceived as basically

\footnotetext{
${ }^{8}$ According to article 13 of the Poland's constitution of 1997, “[p]olitical parties and other organizations whose programmes are based upon totalitarian methods and the modes of activity of nazism, fascism and communism, as well as those whose programmes or activities sanction racial or national hatred, the application of violence for the purpose of obtaining power or to influence the State policy, or provide for the secrecy of their own structure or membership, shall be prohibited".

${ }^{9}$ Gazeta Wyborcza is a Polish liberal newspaper; Trybuna Ludu was from 1948 to 1990 the official newspaper of the Polish United Workers' Party (PZPR); PO/Platforma Obywatelska (Civic Platform) is a liberalconservative political party in Poland. Robert Winnicki, a far-right politician, means here the Second Cabinet of Donald Tusk - a coalition government of the PO and the agrarian, conservative Polish People's Party (PSL).
} 
the same and different only in marginal aspects. The following quote by right-wing politician Janusz Korwin-Mikke may serve as an example.

We surely have to deal with a new form of communism, only in a new disguise. As Coco Chanel used to say: "New and old are the same, only wrapped differently". This holds true for the Law and Justice party as well. They are communists in a new wrapper with a cross on top of it (Korwin-Mikke 2018).

The discursive relations described above can function as modes of arranging discursive elements into coherent strategemes, which in turn constitute a hegemonic strategy.

\section{Hegemonic strategy and its core strategemes}

Every hegemonic strategy is composed of a number of hegemonic strategemes. Nonhoff identifies nine such strategemes, three of which he calls "core strategemes" because they are sufficient to grasp a hegemonic strategy (Nonhoff 2006, 212-221). ${ }^{10}$ Although they are always intertwined in practice, their separate examination can be useful for analytical purposes. After a more detailed examination of these core strategemes, I proceed to discuss the question of how to apply the hegemony analysis as developed by Nonhoff to anti-communist discourse.

\section{(I) Articulation of equivalences between different demands made with regard to the universal}

In the logic of equivalence, different demands are articulated as equivalent, so that a variety of groups and individuals can perceive them as their own. The exemplary structure of such a demand runs as follows: "Your demand is actually the same as ours, so if our demand is fulfilled, so will yours be" (Nonhoff 2006, 214). This articulation of equivalences between different demands leads to the formation of chains of equivalence: " $v, w, x, y$, and $z$ are all different from each other but equivalent with regard to $a$ " (Nonhoff 2006, 87). Such a chain of equivalence forms itself in opposition to a "constitutive outside". ${ }^{11}$ This means that the

10 For additional strategemes identified by Nonhoff, which aim to expand the range of hegemony, see Nonhoff 2006, 211-221.

11 Laclau defines a "constitutive outside" as "an 'outside' which blocks the identity of the 'inside' (and is, nonetheless, the prerequisite for its constitution at the same time)" (Laclau 1990, 17). As Torfing argues, "the constitutive outside of a discourse A, which is discursively constructed by the expansion of a chain of equivalence, is neither B nor non-A, but anti-A" (Torfing 1999, 125). 
equivalent demands are not united by "something positive (...) but something negative: their opposition to a common enemy" (Laclau 1996, 40-41).

\section{(II) Antagonistic division of discursive space}

In the logic of difference, all demands that do not correspond to the central hegemonic demand are also discursively knotted together in a chain of equivalence. The construction of such an opposing chain is an important part of every hegemonic practice. In the end, since "[a]ntagonism 12 does not admit tertium quid" (Laclau 2014 [1985], 115), we reach two antagonistic camps or opposing blocks of demands. These are made up of "the elements of lack, lethargy, and resistance on the one hand (...) and the demand to overcome these negative forces on the other (...)" (Nonhoff 2005). One's own essential demand is contrasted with an antagonistic one, which is perceived and represented as the "core of all evil" (Nonhoff 2006, 220). However, these chains of equivalence are never set permanently, since there is a constant struggle for the creation of differences and new chains of equivalence.

\section{(III) Representation}

Hegemonies are centred on a specific discursive element that is supposed to represent the universal (Nonhoff 2008, 308). Since the universal, for example the common good or an equivalent notion (freedom, wealth), cannot directly actualise itself in a discourse, it needs a "symbolic embodiment" (ibid.). Laclau calls this central demand in which all particular demands are represented an "empty signifier" (Laclau 1996, 34-46). ${ }^{13}$ As he suggests, "[t]he presence of empty signifiers (...) is the very condition of hegemony" (43). He states that

representation is only possible if a particular demand, without entirely abandoning its own particularity, starts also functioning as a signifier representing the chain as a totality

\footnotetext{
12 The term antagonism is understood by Laclau and Mouffe (2014 [1985]) differently than in the Marxist tradition (Nonhoff 2014, 31). It is neither a "real opposition" (A-non A) nor a "logical contradiction" (A-B), since these are objective relations and the objects (real or conceptual) have full identities: "But in the case of antagonism, we are confronted with a different situation: the presence of the 'Other' prevents me from being totally myself. The relation arises not from full totalities, but from the impossibility of their constitution. (...) [A]ntagonisms are not internal but external to society; or rather, they constitute the limits of society, the latter's impossibility of fully constituting itself" (Laclau and Mouffe 2014, 111-112, emphasis in original). However, this conception of antagonism (A-anti-A), as formulated in Hegemony and Socialist Strategy, has evolved in their later work, especially in Laclau's New Reflections on the Revolution of Our Time (1990). For the development of the understanding of antagonism by Laclau and Mouffe see: Torfing 1999, 120-131 and Nonhoff 2017.

${ }^{13}$ To emphasise the process of one element becoming the incarnation of the universal, Nonhoff suggests speaking of "emptied" rather than "empty signifiers" $(2006,132)$.
} 
(in the same way as gold, without ceasing to be a particular commodity, transforms its own materiality into the universal representation of value). This process by which a particular demand comes to represent an equivalential chain incommensurable with it is, of course, what we have called hegemony (Laclau 2005b, 39).

One of his favourite examples of an empty signifier is the Polish trade union Solidarność, whose symbols "[a]t some point (...) became the symbols of the absent fullness of society" (Laclau 2005a, 226):

\begin{abstract}
The demands of Solidarnosc, for instance, started by being the demands of a particular working class group in Gdansk, but as they were formulated in an oppressed society, where many social demands were frustrated, they became the signifiers of the popular camp in a new dichotomic discourse (Laclau 2005b, 39).
\end{abstract}

It is important to note that such an understanding of Solidarność is only possible from today's dominant perspective and is a result of a struggle for its hegemonisation. During the 1980s, the meaning of the movement was still not determined and potentially open to other interpretations. In this sense, Solidarność retroactively became a signifier of the fight against communism only after 1989. ${ }^{14}$

\title{
Communism as a signifier of exclusion
}

How can we transfer concepts from hegemony and discourse theory to the analysis of anticommunist discourse in contemporary Poland? As a result of the antagonistic division of discursive space, it is possible to discern two chains of equivalence. On one side there is everything that contributes to the overcoming of communism ("everything which resolves the lack of the universal"), and on the other there is everything that renders the overcoming of communism impossible ("everything which prevents the successful removal of the lack") (Nonhoff 2006, 216). As Laclau and Mouffe argue, in each discourse one specific logic - either the logic of equivalence or the logic of difference - predominates, which affects the division of discursive space: "[T] he logic of equivalence is a logic of the simplification of political space, while the logic of difference is a logic of its expansion and increasing complexity" (Laclau and Mouffe 2014, 117). When the former preponderates, the discursive space is divided into two clearly opposed camps ("friend" vs. "enemy"), while in the latter such dichotomisation is not

\footnotetext{
14 The mainstream interpretation of Solidarność is challenged by, for example, Jan Sowa, for whom at least the so-called first Solidarność from 1980 was not an anti-communist movement but, on the contrary, "an event par excellence communist" (Sowa 2015, 177).
} 
possible, since constructing "an enemy" is much more difficult (cf. Norval 2000, 221). ${ }^{15}$ Anticommunism is thus an example of a discourse where the logic of equivalence is predominant. As the Razem example shows (see below), it is not possible to take a middle ground - it is necessary to position oneself as anti-communist to be taken seriously in public discourse. Any ambiguous stance is immediately identified as the communist "enemy".

This antagonistic division of discursive space takes on different forms. In mainstream narratives regarding the People's Republic of Poland, the division runs between the "Polish nation" (or society) and the "communist regime". Both are perceived as monolithic blocks: the united, heroic, Catholic nation on the one side and an external enemy, oppression from outside, the embodiment of evil on the other (cf. Żukowski 2009, 5; Chmielewska 2012, 18-20). As a result of this narrative, the history of the People's Republic of Poland is presented only as a curio, a short disturbance of the natural development of Polish society (Chmielewska 2012, 31). For the period after 1989, this division has been replaced by the antagonism between a post-Solidarność and a post-communist camp, which functioned in a very similar way and lasted until 2015, when not a single left-wing party (including the post-socialist Democratic Left Alliance) was elected to parliament. Since then, the main parties within the (former) postSolidarność camp have accused each other of being communist. ${ }^{16}$

Nevertheless, the central promise of these - seemingly opposing - anti-communist discourses stays the same: Polish society will not reach harmony or fullness unless communism, "the core of all evil", is overcome. Communism, as a "general crime", is an obstacle that prevents Polish society "from coinciding with itself, from reaching its own fullness" (Laclau 2000, 142). ${ }^{17}$ The promise to overcome communism takes on different forms, depending on

15 To illustrate this point, Glynos and Howarth refer to struggles of national liberation against colonial occupants. Here, both logics are operative: The logic of equivalence frames this struggle as one of oppressed colonial subjects vs. oppressive colonial regime (thus levelling the class, gender, and other differences among the oppressed), while the logic of difference "draws on other discourses in an attempt to break down these chains of equivalence" (Glynos and Howarth 2007, 144-145), applying a "divide and rule" strategy. The two logics are not "mutually exclusive": They interact with each other and neither can dominate completely (cf. also Torfing 1999, 125-128; Howarth and Stavrakakis 2000, 12).

16 To give one of many examples: On December 27, 2017, then Interior Minister Mariusz Błaszczak announced that communism in Poland had ended just one week previously (when President Duda had signed a new law on the Supreme Court and the National Council of the Judiciary). The leader of the oppositional Civic Platform Grzegorz Schetyna commented on Twitter: "Communism is coming back to Poland and will not end until Law and Justice has fallen into political non-existence" (Schetyna 2017).

17 The phrase "general crime" refers to Karl Marx, who describes the hegemonic operation in which a particular class becomes a representative of the whole society. In order to succeed, "all the defects of society must conversely be concentrated in another class, a particular estate must be the general stumbling-block, the incorporation of the general limitation, a particular social sphere must be looked upon as the notorious crime of the whole of society, so that liberation from that sphere appears as general self-liberation. For one estate to be par excellence the estate of liberation, another estate must conversely be the obvious estate of oppression" (Marx 2010 [1843], 185, emphasis in original). Cf. Laclau 2000. 
who articulates it. It can mean the elimination of some imaginary residue of the People's Republic of Poland, the struggle against alleged new forms of communism (such as "cultural Marxism", "gender ideology", or the European Union) or, last but not least, opposition to the current government of the Law and Justice party. Since these demands can never be completely fulfilled, the hegemony of anti-communism can perpetuate itself:

[T] he hegemonic operation is only possible insofar as it never succeeds in achieving what it attempts (...). For if such a total suture was possible, it would mean that the universal would have found its own undisputed body, and no hegemonic variation would any longer be possible (Laclau 2000, 142).

Can communism function as an empty signifier in this hegemony? Nonhoff would say no. In his view, an empty signifier has to be "positively" loaded in order to "render the universal symbolically accessible" (2006, 129). However, other scholars, such as Philipp Sarasin (2001), Philip Bedall (2014), and Yannis Stavrakakis distinguish between "positive" and "negative" empty signifiers. ${ }^{18}$ As the latter states:

The signifier of exclusion (...) is also an empty signifier, but one that represents the opposite of the point de capiton: ${ }^{19}$ pure negativity, what has to be negated and excluded in order for reality to signify its limits. Reagan's characterisation of the USSR as the evil empire is a good case in point. Here again a particular signifier is "emptied" from its concrete content in order to represent a negative universal (...) (Stavrakakis 1999, 80$81)$.

Communism, as a "negative" empty signifier, provides the over-arching frame for a multitude of "positive" empty signifiers, which do not share any positive common content and may range from liberal democracy to the Catholic Polish nation.

${ }^{18}$ Laclau also takes into consideration the possibility of a negative empty signifier. He states that "[ $\left.t\right]$ he moment of the antagonistic clash, which cannot be directly represented, can however be signified - positivised, if you want - through the production of an empty signifier (or two, rather; one at each side of the antagonistic frontier)" (Laclau 2006, 108).

${ }^{19}$ Lacan's category of "point de capiton" is in Laclau and Mouffe's terminology called a "nodal point": "Any discourse is constituted as an attempt to dominate the field of discursivity, to arrest the flow of differences, to construct a center. We will call the privileged discursive points of this partial fixation, nodal points" (Laclau and Mouffe 2014, 99, emphasis in original). For similarities and differences between a nodal point and an empty signifier see: Howarth 2004, 268-269; Laclau 2004, 322. 


\section{Anti-communist fantasy and its dual character}

Anti-communism, similar to other political discourses, aims "to eliminate anxiety and loss, to defeat dislocation, in order to achieve a state of fullness (...)" (Stavrakakis 1999, 82). However, it does not only promise "a fullness-to-come once a named or implied obstacle [here: communism, M.G.] is overcome", but it also "foretells of disaster if the obstacle proves insurmountable" (Glynos and Howarth 2007, 147). Stavrakakis calls these two dimensions of (hegemonic) discourse the "dual character of fantasy", its "beatific and (...) horrific dimension" $(1999,52) .{ }^{20}$ Both aspects "are inseparable and mutually constitutive" (Glynos 2001, 88). It is against this background that one should read the following statement of MP Krystyna Pawłowicz of the ruling Law and Justice party:

Only now, 27 years after 1989, is a true revolution against communism and the People's Republic of Poland taking place. It is a battle over life and death. (...) The Law and Justice party faces a historic task. In order to ensure the survival of the country, it must win this battle (Pawłowicz 2016).

The battle against communism is also waged by a major part of the Polish left. For them, as Agnieszka Mrozik notes:

[T] he communist project and the people connected to it - especially after the Second World War - [are] the proverbial ball and chain or an unpleasant surprise, meaning a kind of burden, disgrace, trouble (...). It is like an unpleasant smell that one cannot get rid of, like dirt that sticks like a leech despite repeated attempts at disinfection (Mrozik 2014).

These attempts at "disinfection" are symptomatic of the way the Polish left deals with the communist legacy. For example, the standard reaction of the social democratic party Razem to "accusations" of being communist is to create a relation of super-difference. When a journalist asked Marcelina Zawisza whether she was a communist, she answered:

No. If someone has difficulties distinguishing between communism and social democracy, they did not pay attention in social sciences at school. The solutions that

${ }^{20}$ Glynos defines fantasy as "a framing device that subjects use to 'protect' themselves from the anxiety associated with the idea that there is no ultimate guarantee or law underlying and guiding our social existence" (Glynos 2011, 70). 
we propose do not stem from communism but have their roots in Western Europe (Zawisza 2017).

The same argumentative structure can be observed in the following statement by the party's most prominent figure, Adrian Zandberg:

You must have seriously defective vision to see in us fans of Jaruzelski. (...) It is enough to look at the election programme of Razem to notice that our proposals follow the example of Northern Europe (Zandberg 2016).

It is telling that both Zawisza and Zandberg deny any connection between social democracy and communism. Communism here is identified with the political leader of the People's Republic of Poland and implicitly with the East. In this narrative, Polish society, including the left, must overcome this burden of Eastern communism in order to become part of Western or Northern Europe. In this line of argumentation, we can also identify Stavrakakis' "dual character of fantasy": The Western welfare state being the beatific promise, while its horrific dimension is the threat of Poland becoming a second version of "Putin's Russia". ${ }^{21}$

Using a strategy that denies any connections to communism as a political legitimisation and to prevent any kind of penalisation (see ft. 8), Razem reproduces anti-communism and consolidates its hegemony. The party's strategy can be understood as an attempt to defend its "membership in the Polish national and social community" (OSKiLnK [Żukowski], 228). As Tomasz Żukowski puts it:

Debates about peoples' connection to communism aroused and still arouse so many emotions because what is at stake is symbolic power. To stigmatise someone as a communist means depriving them of the right to participate in public life (Żukowski 2009, 4).

In this sense, anti-communism can be perceived as a typical discourse of exclusion, and it is worthwhile to see it in conjunction with other discourses, such as (Catholic) nationalism and antisemitism. For Elżbieta Janicka, an ethnic-religious and an anti-communist doxa are the social-cultural frame in contemporary Poland; "[b]oth paradigms overlap and both are potentially - if not structurally - built on antisemitism" (Janicka 2016). Anti-communist

\footnotetext{
21 These two scenarios - beatific and horrific - are put in a nutshell by Maciej Konieczny, a member of the board of the Razem party: "The question is: Do we want to live in a well-functioning European country or in Putin’s Russia?” (Konieczny 2015).
} 
discourse, at least its right-wing variant, works similar to the fascist one in which "the presupposed organic unity of society is perturbed by the intrusion of a foreign body" (Žižek 2008, 261). In such discourses "the (class) antagonism inherent in the social structure" (ibid.) is externalised, the imaginary harmony is disturbed by an external intruder. This "intruder from outside" often takes the form of a (Jewish) communist. Zukowski describes him as follows:

[A communist] has a thousand faces and turns up in the least expected place. He is a ghost from the past and a still dangerous, hidden enemy; a foreign occupier and a frustrated, familiar "homo sovieticus", not pleased with free Poland. He feels great in the new reality, makes "connections" and drums up corruption in the highest circles of business and politics, and - at the same time - organises demanding strikes and does not give a damn about market reforms. On the one hand, he sucks blood from the Polish people as the enfranchised nomenklatura, and on the other - damages the economy with preposterous, extreme leftist ideas. (...) He is an antisemite from March '68 but also an anti-Polish Jew. (...) His only useful characteristic - he is permanently foreign (Żukowski 2009, 4).

Jason Glynos and David Howarth argue that where the logic of equivalence predominates, "fantasmatic logics may take the form of a narrative in which an internal obstacle (or "enemy within") is deemed responsible for the blockage of identity, while promising a fullness or harmony to come" (Glynos and Howarth 2007, 150, emphasis in original). On the other hand, within the logic of difference an external enemy or obstacle is deemed to be a threat to an already existing fullness and harmony. However, things are not as simple in this case because in anti-communist discourse, both narratives are merged together: The communist as an "enemy within" is often externalised - marked as a Jew, a western cultural Marxist, a Russian Bolshevik, etc. - and thereby declared a threat to the anti-communist Polish nation.

\section{Conclusion}

In this article, I have selectively applied hegemony analysis to anti-communist discourse in contemporary Poland. The whole analytical praxis, as developed by Martin Nonhoff, is composed of six steps: 1. preparatory work; 2. selection/design of the discourse corpus; 3. structure of the analysis; 4. analysis of single texts and their context; 5 . analysis beyond the single text/on the discourse level; 6 . checking the validity of the strategemes (Nonhoff 2008, 316-318; Nonhoff 2019, 84-99).

Nevertheless, even without the whole process of analysis, it is possible to recognise the benefits, challenges, and limitations regarding the application of this methodology to anticommunist discourse. One important advantage is that it forces us to limit the research 
question, which - in the case of such a complex issue as anti-communism - is necessary. Hegemony analysis focuses on the functioning of hegemony (with hegemony understood as the function of discourse) (Nonhoff 2008, 300). It is not suited for the reconstruction of the conditions and the genesis of anti-communism or for the exploration of the motivations of anti-communists and their goals, ${ }^{22}$ and it does not ask why its hegemony is so successful or what its functions are. It is rather aimed at finding typical mechanisms and structures of anticommunist discourse.

Another methodological benefit of this approach is that - widening the scope of discourse analysis - it enables us to focus not only on texts but also on political actions, social interventions, institutions, law-making processes, or events, since "every social configuration is meaningful' (Laclau and Mouffe 1987, 82, emphasis in original), and "[a]s long as every nonlinguistic action is meaningful, it is also discursive" (85). ${ }^{23}$ Finally, hegemony analysis allows us to perceive anti-communism as a hegemony, meaning as a widely shared consensus, thus enabling us to focus our research not only on the "usual suspects" (i.e. conservative and rightwing anti-communists) but also on how the discourse is internalised and reproduced by leftist groups.

Moreover, Nonhoff's detailed description of the analytical procedure provides a clear structure that helps to operationalise Laclau and Mouffe's theory. Of course, this application cannot be simply mechanical. One should "avoid the twin pitfalls of empiricism and theoreticism", as Howarth and Stavrakakis warn:

[T]nstead of applying a pre-existing theory on to a set of empirical objects, discourse theorists seek to articulate their concepts in each particular enactment of concrete research. The condition for this conception of conducting research is that the concepts and logics of the theoretical framework must be sufficiently "open" and flexible enough to be adopted, deformed and transformed in the process of application (Howarth and Stavrakakis 2000, 5).

Like every methodological approach, hegemony analysis has its limitations. Due to the strong focus on the functioning of hegemony, other important research questions are necessarily disregarded. It is, for example, debatable whether one can sufficiently grasp continuities and

\footnotetext{
22 As Ole Wæver notes, discourse analysis "does not try to get to the thoughts or motives of the actors, their hidden intentions or secret plans. (...) What is often presented as a weakness of discourse analysis - how do you find out if they really mean it?', 'what if it is only rhetoric?' - can be turned into a methodological strength, as soon as one is scrupulous about sticking to discourse as discourse" (Wæver 2005, 33, emphasis in original).

${ }^{23}$ However, according to Nonhoff, this does not hold for physical violence that marks the limit of discourse (Nonhoff 2006, 11). This assumption appears questionable, since it is not clear in what regard acts of violence differ from other non-linguistic discursive actions.
} 
abrupt changes in the history of anti-communism using hegemony analysis, even though it perceives hegemony not as something static but as a continuous process. The same can be said about the reasons for the rise of anti-communism, its socio-economic conditions, and its functions. Moreover, hegemony analysis might not be the best approach for a comparison of different kinds of anti-communism (e.g. social democratic, liberal, and fascist), which are all understood as parts of one all-encompassing hegemony.

Nevertheless, the sound theoretical framework of hegemony analysis can serve as a good introductory step for researching anti-communism in contemporary Poland. In return, hegemony analysis, as a problem-driven approach, can also benefit from its application to this specific discourse, so that, in a best-case scenario, both anti-communism research and hegemony analysis learn from each other. As Jacob Torfing puts it: "The challenge is to go beyond illustrative analysis and conduct discourse analysis in order to produce new, unexpected insights and sharpen the theoretical categories and arguments" (Torfing 2000, 26). 


\section{References}

Bedall, Philip. 2014. Climate Justice vs. Klimaneoliberalismus? Kilmadiskurse im Spannungsfeld von Hegemonie und Gegen-Hegemonie. Bielefeld: Transcript Verlag.

Blatman, Daniel. 1997. "Polish Antisemitism and 'Judeo-Communism': Historiography and Memory". East European Jewish Affairs 27(1): 23-43.

Buchowski, Michał. 2013. "Neoliberalizm w Europie Środkowej - magia, religia czy nauka?”. Poznańskie Studia Slawistyczne 4: 29-41.

Ceplair, Larry. Anti-Communism in Twentieth-Century America: A Critical History. Santa Barbara, CA: Praeger.

Chmielewska, Katarzyna. 2012. "Komunizm w perspektywie historiografii współczesnej: Próba ujęcia”. In PRL \&̇ycie po syciu, eds. Katarzyna Chmielewska, Agnieszka Mrozik, and Grzegorz Wołowiec. Warszawa: Wydawnictwo IBL PAN.

Creuzberger, Stefan and Dirk Hoffmann (eds.). 2014. 'Geistige Gefahr' und 'Immunisierung der Gesellschaft': Antikommunismus und politische Kultur in der frühen Bundesrepublik. München: Oldenbourg Verlag.

Critchley, Simon. 2004. "Is There a Normative Deficit in the Theory of Hegemony?". In Laclau. A Critical Reader, eds. Simon Critchley and Oliver Marchart: London-New York: Routledge.

Faulenbach, Bernd. 2011. "Erscheinungsformen des 'Antikommunismus': Zur Problematik eines vieldeutigen Begriffs". Jahrbuch für Historische Kommunismusforschung. 1-14.

Faulenbach, Bernd. 2017. "Antikommunismus" (Version: 1.0). Docupedia-Zeitgeschichte, http://docupedia.de/zg/Faulenbach_antikommunismus_v1_de_2017.

Forecki, Piotr. 2017. "Fantazmat Julii Brystiger”. Środkowoeuropejskie Studia Politycæne 1: 47-69.

Fried, Albert. 1997. McCarthyism: The Great American Red Scare. A Documentary History. New York: Oxford University Press.

Gerrits, André. 1995. "Antisemitism and Anti-Communism: The Myth of 'JudeoCommunism' in Eastern Europe”. East European Jewish Affairs 25(1): 49-72.

Glynos, Jason. 2011. "Fantasy and Identity in Critical Political Theory”. Filozofski vestnik, 32(2): 65-88.

Glynos, Jason and David Howarth. 2007. Logics of Critical Explanation in Social and Political Theory. London: Routledge.

Glynos, Jason and Yannis Stavrakakis. 2004. "Encounters of the Real Kind: Sussing out the Limits of Laclau's Embrace of Lacan". In Laclau: A Critical Reader, eds. Simon Critchley and Oliver Marchart. London-New York: Routledge.

Gramsci, Antonio. 1999. Selections from the Prison Notebooks. London: The Electric Book Company. 
Heale, Michael J. 1990. American Anti-Communism: Combating the Enemy Within, 1830-1970. Baltimore: Johns Hopkins University Press.

Heale, Michael J. 1998. McCarthy's Americans: Red Scare Politics in State and Nation, 1935-1965. Basingstoke: Macmillan Press.

Herer, Michał. 2017. “Komuniści i złodzieje”. Dwutygodnik 218. https://www.dwutygodnik.com/artykul/7322-komunisci-i-zlodzieje.html.

Holubec, Stanislav and Agnieszka Mrozik. 2018. Historical Memory of Central and East European Communism. New York-London: Routledge.

Howarth, David. 2004. "Hegemony, Subjectivity, Democracy". In Laclau: A Critical Reader, eds. Simon Critchley and Oliver Marchart. London-New York: Routledge.

Howarth, David, Aletta Norval and Yannis Stavrakakis (eds.). 2000. Discourse Theory and Political Analysis: Identities, Hegemonies and Social Change. Manchester: University Press.

Howarth, David and Jacob Torfing. 2005. Discourse Theory in European Politics: Identity, Policy and Governance. Basingstoke: Palgrave Macmillan.

Howarth, David and Yannis Stavrakakis. 2000. "Introducing discourse theory and political analysis". In Discourse Theory and Political Analysis: Identities, Hegemonies and Social Change, eds. David Howarth, Aletta Norval, and Yannis Stavrakakis. Manchester: University Press.

Janicka, Elżbieta. 2016. "O kontrkulturę - tu i teraz". Recykling Idei. http:// recyklingidei.pl/janicka-o-kontrkulture-tu-teraz.

Kapmann, Margot, Elfriede Müller, and Krunoslav Stojaković. 2017. "Die Aktualität des Antikommunismus". In Anti! Kommunismus. Struktur einer Ideologie, ed. Jour Fixe Initiative Berlin. Münster: Edition Assemblage.

Konieczny, Maciej. 2015. "Partia Razem: Polska nie jest najgorszym miejscem na Ziemi, ale mogłaby być miejscem dużo lepszym” (interview with Maciej Konieczny and Marcelina Zawisza). https://opinie.wp.pl/partia-razem-polska-nie-jest-najgorszym-miejscem-naziemi-ale-moglaby-byc-miejscem-duzo-lepszym-6016710606066305a.

Korte, Jan. 2009. Instrument Antikommunismus: Der Sonderfall Bundesrepublik. Berlin: Dietz Verlag.

Korwin-Mikke, Janusz. 2018. https:/ /www.facebook.com/janusz.korwin.mikke/ posts/10155576356592060.

Körner, Klaus. 2003. Die rote Gefahr: Antikommunistische Propaganda in der Bundesrepublik 19502000. Hamburg: Konkret Literatur Verlag.

Laclau, Ernesto. 1990. New Reflections on the Revolution of Our Time. London: Verso.

Laclau, Ernesto. 1995. “The Time is Out of Joint”. Diacritics 25(2): 86-96.

Laclau, Ernesto. 1996. Emancipation(s). London-New York: Verso. 
Laclau, Ernesto. 2000. "Power and Social Communication”. Ethical Perspectives 7: 139-145.

Laclau, Ernesto. 2004. "Glimpsing the Future”. In Laclau: A Critical Reader, eds. Simon Critchley and Oliver Marchart. London-New York: Routledge.

Laclau, Ernesto. 2005a. On Populist Reason. London: Verso.

Laclau, Ernesto. 2005b. "Populism: What's in a Name?". In Populism and the Mirror of Democracy, ed. Francisco Panizza: London-New York: Verso.

Laclau, Ernesto. 2006. "Why Constructing a People Is the Main Task of Radical Politics". Critical Inquiry 32(4): 646-680.

Laclau, Ernesto and Chantal Mouffe. 1987. "Post-Marxism without Apologies". New Left Review 166: 79-106.

Laclau, Ernesto and Chantal Mouffe. 2014 [1985]. Hegemony and Socialist Strategy: Towards a Radical Democratic Politics. London-New York: Verso.

Lipiński, Artur. 2005. Antykomunistyczne oblicze polskiej prawicy u schytku XX wieku - analiza dyskursu politycznego. Poznań: Uniwersytet im. Adama Mickiewicza (unpublished dissertation)

Marx, Karl. 2010 [1843]. "Contribution to the Critique of Hegel's Philosophy of Law: Introduction”. In Karl Marx and Frederick Engels. Collected Works, vol. 3. London: Lawrence \& Wishart.

Mazowiecki, Tadeusz. 1989. https://dzieje.pl/aktualnosci/wystapienie-tadeuszamazowieckiego-w-sejmie-24-sierpnia-1989-r.

Mrozik, Agnieszka. 2014. "Poza nawiasem historii (kobiet), czyli po co nam dziś komunistki”. Wakat On-line 3. http:/ / wakat.sdk.pl/poza-nawiasem-historii-kobiet-czyli-po-co-namdzis-komunistki/.

Mrozik, Agnieszka. 2015. https://www.youtube.com/watch?v=9hNTnJXQbbk.

Murray, Robert K. 1964. Red Scare: A Study in National Hysteria, 1919-1920. New York: McGraw-Hill.

Nonhoff, Martin. 2005. "Social Market Economy as a Hegemonic Project: An Exercise in Functionalist Discourse Analysis". Lecture on July 1'st, 2005, Paris XII, Créteil. http://www.johannes-angermuller.net/deutsch/ADFA/nonhoff.pdf.

Nonhoff, Martin. 2006. Politischer Diskurs und Hegemonie. Das Projekt 'Soziale Marktwirtschaft'. Bielefeld: Transcript Verlag.

Nonhoff, Martin. 2007. “Diskurs, radikale Demokratie, Hegemonie - Einleitung”. In Diskurs - radikale Demokratie - Hegemonie: Zum politischen Denken von Ernesto Laclau und Chantal Mouffe, ed. Martin Nonhoff. Bielefeld: Transcript Verlag.

Nonhoff, Martin. 2008. "Hegemonieanalyse: Theorie, Methode und Forschungspraxis". In Handbuch Sozialwissenschafte Diskursanalyse, Band 2: Forschungspraxis, eds. Rainer Keller, 
Andreas Hirseland, Werner Schneider, and Willy Viehöver. Wiesbaden: VS Verlag für Sozialwissenschaften.

Nonhoff, Martin. 2014. “Antagonismus”. In DiskursNetz: Wörterbuch der interdisziplinären Diskursforschung, eds. Daniel Wrana, Alexander Ziem, Martin Reisigl, Martin Nonhoff, and Johannes Angermuller. Berlin: Suhrkamp Verlag.

Nonhoff, Martin. 2017. "Antagonismus und Antagonismen - hegemonietheoretische Aufklärung”. In Ordnungen des Politischen. Einsätze und Wirkungen der Hegemonietheorie Ernesto Laclaus, ed. Oliver Marchart. Wiesbaden: Springer VS.

Nonhoff, Martin. 2019. "Hegemony Analysis: Theory, Methodology and Research Practice". In Discourse, Culture and Organization: Postdisciplinary Studies in Discourse, ed. Tomas Marttila. Cham: Palgrave Macmillan.

Norval, Aletta J. 2000. "Trajectories of Future Research in Discourse Theory”. In Discourse Theory and Political Analysis: Identities, Hegemonies and Social Change, eds. David Howarth, Aletta J. Norval, and Yannis Stavrakakis: Manchester-New York: Manchester University Press.

Opratko, Benjamin. 2012. "Ein theoretischer Universalschlüssel? Zur Ontologisierung des Hegemoniebegriffs bei Laclau und Mouffe". In Diskurs und Hegemonie.

Gesellschaftskritische Perspektiven, eds. Iris Dzudzek, Caren Kunze, and Joscha Wullweber. Bielefeld: Transcript Verlag.

Ośrodek Studiów Kulturowych i Literackich nad Komunizmem Instytutu Badań Literackich (OSKiLnK) Polskiej Akademii Nauk. 2013. “Dyskusja Ośrodka Studiów Kulturowych i Literackich nad Komunizmem IBL PAN: Komunizm i PRL dzisiaj”. Teksty Drugie 3: 227-244.

Pawłowicz, Krystyna. 2016. https://www.facebook.com/KrystynaPawlowicz/posts/ dopiero-terazw-27-lat-po-1989r-trwa-w-polsce-prawdziwa-rewolucjaantykomunistycz/1288375817901470/.

Pufelska, Agnieszka. 2007. Die 'Judäo-Kommune'-Ein Feindbild in Polen. Das polnische Selbstverständnis im Schatten des Antisemitismus 1939-1948. Paderborn: Schöningh.

Sarasin, Philipp. 2003. Geschichtswissenschaft und Diskursanalyse. Frankfurt am Main: Suhrkamp. Saryusz-Wolska, Magdalena, Sabine Stach and Katrin Stoll. 2016. "Verordnete Geschichte? Zur Dominanz nationalistischer Narrative in Polen: Eine Einführung". Zeitgeschichteonline. https:/ / zeitgeschichte-online.de/thema/verordnete-geschichte-zur-dominanznationalistischer-narrative-polen.

Saussure, Ferdinand de. 1959. Course in General Linguistics. New York: Philosophical Library. Schetyna, Grzegorz. 2017. https://twitter.com/SchetynadlaPO/status/945921932142305281. 



Wydawnictwo W.A.B.

Starnawski, Marcin. 2012. "Tęsknię za tobą, Żydzie-rewolucjonisto! Demitologizacja, etos i nieprawomyślne lekcje w filmie Anny Zawadzkiej Żydokomuna”. Recykling Idei 13: 162_ 176.

Stavrakakis, Yannis. 1999. Lacan and the Political. London-New York: Routledge.

Stavrakakis, Yannis. 2003. "Laclau with Lacan: Comments on the Relation between Discourse Theory and Lacanian Psychoanalysis". In Jacques Lacan: Critical Evaluations in Cultural Theory, ed. Slavoj Žižek. London: Routledge.

Storrs, Landon R.Y. 2013. The Second Red Scare and the Unmaking of the New Deal Left. Princeton-Oxford: Princeton University Press.

Śpiewak, Paweł. 2012. Żydokomuna: Interpretacje historyczne. Warszawa: Wydawnictwo Czerwone i Czarne.

Torfing, Jacob. 1999. New Theories of Discourse: Laclau, Mouffe and Žižek. Oxford: Blackwell Publishers.

Traverso, Enzo. 2016. "The New Anti-Communism: Rereading the Twentieth Century". 23 August. https://www.versobooks.com/blogs/2811-enzo-traverso-the-new-anticommunism-rereading-the-twentieth-century.

Walicki, Andrzej. 2013. Od projektu komunistycznego do neoliberalnej utopii. Kraków: Universitas.

Waszczykowski, Witold and Hans-Jörg Vehlewald. 2016. "Haben die Polen einen Vogel? BILD-Interview mit Polens Außenminister”. BILD-Zeitung, January 3. https://www.bild.de/politik/ausland/polen/hat-die-regierung-einen-vogel-44003034.

Wæver, Ole. 2005. "European Integration and Security: Analysing French and German Discourses on State, Nation, and Europe". In Discourse Theory in European Politics: Identity, Policy and Governance, eds. David Howarth and Jacob Torfing. Basingstoke: Palgrave Macmillan.

Wielgosz, Przemysław. 2017. "Konsens antykomunistyczny". Le Monde Diplomatique - edycja polska. July. https://monde-diplomatique.pl/LMD137/index.php?id=1_2.

Winnicki, Robert. 2012. "List otwarty Prezesa MW do gen. Zbigniewa Ścibor-Rylskiego". https://www.pch24.pl/list-otwarty-prezesa-mw-do-gen—zbigniewa-scibor---rylskiego,4743,i.html.

Wippermann, Wolfgang. 2012. Heilige Hetrijagd: Eine Ideologiegeschichte des Antikommunismus. Berlin: Rotbuch Verlag.

Zandberg, Adrian. 2016. "Komunistami nie jesteśmy. SLD zatonęło samo, bez naszej pomocy" (interview by Marta Gawina). Kurier Poranny, April 26. https://poranny.pl/adrian-zandberg-komunistami-nie-jestesmy-sld-zatonelo-samo-beznaszej-pomocy/ar/9916658. 
Zawadzka, Anna. 2009. “Żydokomuna”. Bez Dogmatu 79: 13-15.

Zawadzka, Anna. 2012. "Kawior w sowieckiej ambasadzie”. Recykling Idei 13: 177-184.

Zawadzka, Anna. 2016. "Żydokomuna: The Construction of the Insult”. In World War II and

Two Occupations. Dilemmas of Polish Memory, eds. Piotr Forecki and Anna Wolff-Powęska.

Frankfurt am Main: Peter Lang.

Zawisza, Marcelina. 2017. "Jeśli nie zabiłby mnie rak, umarłabym z głodu” (interview by

Piotr Witwicki). Rzeczpospolita, February 2. https://www.rp.pl/Plus-Minus/302029880-

Marcelina-Zawisza---Jesli-nie-zabilby-mnie-rak-umarlabym-z-glodu.html.

Žižek, Slavoj. 2008. In Defence of Lost Causes. London-New York: Verso.

Žižek, Slavoj. 2009. "Post-Wall: Neo-Anti-Communism”. London Review of Books 31(22): 10.

Żukowski, Tomasz. 2009. "Polskie ja idealne”. Bez Dogmatu 79: 4-6.

Żukowski, Tomasz. 2012. “Antykomunizm - technika dyscyplinarna”. Præ̌ekrój 26: 42-44. 
Michalina Golinczak is a PhD candidate at the Center for Interdisciplinary Polish Studies at the European University Viadrina Frankfurt (Oder).

\section{ADDRESS:}

Zentrum für Interdisziplinäre Polenstudien

Europa-Universität Viadrina Frankfurt (Oder)

Große Scharrnstraße 59

D-15230 Frankfurt (Oder)

EMAIL: golinczak@europa-uni.de

Citation: "Communism as a General Crime: Applying Hegemony Analysis to AntiCommunist Discourse in Contemporary Poland”. Praktyka Teoretyczna 1(31): 94-117.

DOI: $10.14746 /$ prt.2019.1.5

\section{Autor: Michalina Golinczak}

TYTUŁ: Komunizm jako powszechne przestępstwo: przyczynek do analizy hegemonii dyskursu antykomunistycznego we współczesnej Polsce

ABSTRAKT: Załamanie się systemu socjalistycznego w Europie Wschodniej wiązało się z rozkwitem antykomunizmu, który w Polsce stał się jednym z dominujących dyskursów politycznych. Jest on ugruntowany w ustawodawstwie, oddziałuje na nauki społeczne i edukację, przenika kulturę popularną i pamięć zbiorową oraz wpływa na bieżące działania polityczne. Mimo to wciąz brakuje systematycznych analiz jego hegemonii. W niniejszym artykule podejmuję próbę zastosowania metodologii wypracowanej przez Martina Nonhoffa w oparciu o teorię dyskursu Ernesta Laclaua i Chantal Mouffe do dyskursu antykomunistycznego we współczesnej Polsce. Argumentuję, że w efekcie antagonistycznego podziału przestrzeni dyskursywnej komunizm staje się „powszechnym przestępstwem”, przeszkodą, która uniemożliwia polskiemu społeczeństwu pojednanie się z samym sobą i osiagnięcie (mitycznej) pełni.

SŁOWA KLUCZOWE: antykomunizm, dyskurs, hegemonia, Laclau, Mouffe, Nonhoff 